\title{
"Audit of banks as public interest entities: Segmentation and conjuncture of the bank audit market in Ukraine"
}

\begin{tabular}{|c|c|}
\hline \multirow{5}{*}{ AUTHORS } & Victor Sukhonos (D https://orcid.org/0000-0001-5520-0227 \\
\hline & Yulia Serpeninova (D https://orcid.org/0000-0002-4448-3484 \\
\hline & Serhiy Makarenko (D https://orcid.org/0000-0001-6455-3585 \\
\hline & Viktoriia Levkulych (D https://orcid.org/0000-0002-8839-7182 \\
\hline & Galina M. Kolisnyk (D https://orcid.org/0000-0003-1417-6608 \\
\hline ARTICLE INFO & $\begin{array}{l}\text { Victor Sukhonos, Yulia Serpeninova, Serhiy Makarenko, Viktoriia Levkulych and } \\
\text { Galina M. Kolisnyk (2021). Audit of banks as public interest entities: } \\
\text { Segmentation and conjuncture of the bank audit market in Ukraine. Banks and } \\
\text { Bank Systems, 16(1), 138-151. doi:10.21511/bbs.16(1).2021.13 }\end{array}$ \\
\hline DOI & http://dx.doi.org/10.21511/bbs.16(1).2021.13 \\
\hline RELEASED ON & Tuesday, 23 March 2021 \\
\hline RECEIVED ON & Monday, 01 February 2021 \\
\hline ACCEPTED ON & Wednesday, 10 March 2021 \\
\hline LICENSE & $\begin{array}{l}(c) \text { EY } \\
\text { This work is licensed under a Creative Commons Attribution } 4.0 \text { International } \\
\text { License }\end{array}$ \\
\hline JOURNAL & "Banks and Bank Systems" \\
\hline ISSN PRINT & $1816-7403$ \\
\hline ISSN ONLINE & $1991-7074$ \\
\hline PUBLISHER & LLC "Consulting Publishing Company "Business Perspectives" \\
\hline FOUNDER & LLC "Consulting Publishing Company "Business Perspectives" \\
\hline
\end{tabular}

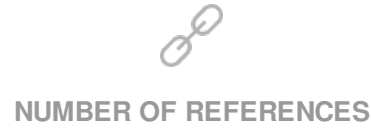

24

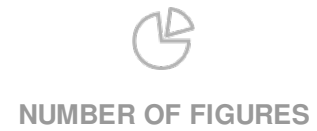

6

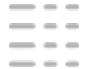

NUMBER OF TABLES

6

(C) The author(s) 2023. This publication is an open access article. 


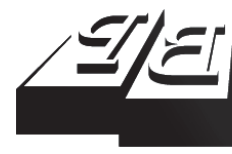

\section{BUSINESS PERSPECTIVES}

(O)

LLC "CPC "Business Perspectives" Hryhorii Skovoroda lane, 10, Sumy, 40022, Ukraine www.businessperspectives.org
Received on: $1^{\text {st }}$ of February, 2021 Accepted on: $10^{\text {th }}$ of March, 2021 Published on: $23^{\text {rd }}$ of March, 2021

(C) Victor Sukhonos, Yulia Serpeninova, Serhiy Makarenko, Viktoriia Levkulych, Galina M. Kolisnyk, 2021

Victor Sukhonos, Professor, Doctor of Law, Sumy State University, Ukraine.

Yulia Serpeninova, Associate Professor, Ph.D., Sumy State University, Ukraine.

Serhiy Makarenko, Chief Auditor, AF LLC “Sumycoop-audit”, Sumy, Ukraine. (Corresponding author)

Viktoriia Levkulych, Ph.D. (Economics), Department of Accounting and Audit, Uzhhorod National University, Ukraine.

Galina M. Kolisnyk, Doctor of Economics, Associate Professor Professor of the Department of Accounting and Auditing, Uzhgorod National University, Ukraine.
Victor Sukhonos (Ukraine), Yulia Serpeninova (Ukraine), Serhiy Makarenko (Ukraine), Viktoriia Levkulych (Ukraine), Galina M. Kolisnyk (Ukraine)

\section{AUDIT OF BANKS AS PUBLIC INTEREST ENTITIES: SEGMENTATION AND CONJUNCTURE OF THE BANK AUDIT MARKET IN UKRAINE}

\begin{abstract}
An important factor in restoring the confidence of financial consumers in banks is to provide auditors with credible and detailed financial statements and their solvency. This study is a pilot step in clarifying the auditor's role in ensuring the banks' reliability as public interest entities in Ukraine. It is aimed at investigating the segmentation of the banking audit services market in Ukraine and its comprehensive characteristics. Structural and dynamic analysis were applied to investigate market, regional and branch concentration, as well as main trends in bank audit market development within the data and registers of the Audit Chamber of Ukraine (ACU) and 75 annual reports of Ukrainian banks. Key aspects of the bank audit market in Ukraine are highlighted: the potential of the bank audit market, the ability of auditors to provide audit services and current characteristics of market conjuncture. Bank audit market is highly segmented: this study differentiates strong segments of international audit networks, associations and alliances, including Big 4 companies and the segment of weak Ukrainian audit companies. Kyiv and Kyiv region are the dominant economic active regions in terms of the regional bank market concentration and the presence of international audit networks. The study results are the basis for improving the regulation of the banking audit services market by the National Bank of Ukraine and ACU.
\end{abstract}

\section{Keywords} assurance, bank solvency, segment, B4, mid-tier accounting companies

JEL Classification

Q01, G21, M40, M41

\section{INTRODUCTION}

Restoring financial consumer confidence in the banking sector after financial crashes requires guarantees for their reliability and solvency. An essential factor in building up trust is assuring auditors about the reliability and completeness of banks' financial statements as public interest entities (PIEs).

The global crisis of 2007-2009 showed the ambiguity of the largest audit companies' (B4) roles during the financial difficulties and bankruptcies of well-known banks such as Lehman Brothers (auditor Ernst \& Young (EY), USD 31 million of fine) and Wachovia (KPMG, USD 31 million) (The Guardian, 2010). In Poland, the public interest entity - a listed company Get Back S.A. paid PLN 6.9 million to its auditor Deloitte Touche Tohmatsu (Dt) in 2018 and after his bankruptcy demanded compensation in the amount of PLN 307 million from Dt for undetected mistakes in financial reporting (Rewczuk \& Modzelewski, 2019).

Due to the embarrassing situation with the JSC CB "PrivatBank" nationalization in 2015, the Price Waterhouse Coopers (PwC) auditor' 
role was analyzed in detail by the National Bank of Ukraine (NBU). That was made to confirm its unreliable financial statements for 2015, which probably led to the bankruptcy of the bank.

A key aspect of poor JSC CB "PrivatBank" reporting is overstated amounts of the mortgaged property, which auditors confirmed as reliable and fairly assessed. That is why B4 company was temporarily excluded from the Ukrainian market of banking audit services. It was due to the running out of the license and exclusion from the register (FT, 2017). In addition to this prime example for the bank audit market in Ukraine, during 2014-2020, more than ten incidents with bank auditors took place. They provided positive conclusions on the reliability of banks' financial statements and their subsequent solvency. This fact raises the issue of protecting financial services consumers' interests from banks' insolvency as public interest entities through the audit assurance mechanisms.

Despite the strict regulation imposed upon audit practice in the Ukrainian banking sector (from the National Bank of Ukraine (NBU) and the Audit Chamber of Ukraine (ACU)), the compliance of national audit legislation with EU Directives (Directive 2006/43/EU, Directive 2013/34/EU, Regulation (EU) No 537/2014) is in the process (EU, 2006, 2013, 2014). The banking audit services market is forming, and its parameters and conditions need to be described with providing dynamic-structural characteristics. A separate field of research is aimed at analyzing the B4 companies' impact as systemically important audit companies and their role in ensuring the solvency of systemically important banks.

The key idea of the paper is to formalize the parameters of the bank audit market, in particular its regional and companies' concentration, main trends of the market, its staffing and separation of market segments. These parameters create a basis for understanding the current market situation and the decision to implement regulatory interventions by the NBU and ACU to ensure confidence in banks as public interest entities and auditors as verifiers of their reporting.

\section{LITERATURE}

\section{AND REGULATORY} SOURCES REVIEW

\subsection{Bank and audit quality as a guarantee for financial services consumers}

The role of auditors in ensuring the reliability of banks' reporting as complex financial institutions has been the subject of research for a long time. The generalization of the experience of audit firms in the context of ensuring the quality of bank reporting and ensuring the confidence of consumers of financial services was conducted by Bratten et al. (2019).

Zhuravka et al. (2020) investigated epy key issues of integrated reporting and auditing of bank institutions.

The characteristics of the bank audit market became especially important after the global finan- cial crisis of 2007-2009 and large-scale interventions of states and central banks to maintain banking systems and prevent the bankruptcy of systemically important banks. The cases of insolvent giant banks and the role of audit firms in their bankruptcies were studied by Jin et al. (2011), Norton (2012), Huizinga and Laeven (2012). Wiggins et al. (2019) represented systematic study of Lehman Brothers bankruptcy and role of EY in it.

In Ukraine, the bank audit market has been insufficiently studied in academic circles. General questions about the audit of banks' reporting in the context of confirmation of their management report were analyzed by Makarenko et al. (2020). Shendryhorenko and Shevchenko (2018) provided an overview of the stages of formation, problems and prospects of the audit market in Ukraine, and the bank audit market in this context. Ensuring the quality of audit in Ukraine and its dual nature is the subject of research in the work of Redko (2020).

At the same time, the conjuncture characteristics of the bank audit market in Ukraine, the existing 
segments of audit companies, the market potential with a special emphasis on the division of companies into international audit networks, associations and alliances (IANAA), including B4, and Ukrainian audit companies, need to be studied.

This study is aimed at investigating the segmentation of the banking audit services market in Ukraine and its comprehensive characteristics in the following aspects:

1) the potential of the bank audit market (financial sector and banks in Ukraine as an audit entity);

2) the ability of auditors to provide audit services (ACU requirements and additional NBU criteria); and

3) the development of the banking system potential and the auditors' capacity that form the current market situation.

\subsection{Audit of a bank as a PIE? in Ukraine: regulatory issues}

In compliance with the requirements of Directive 2006/43/EU of the European Parliament and of the Council of 17 May 2006 on statutory audits of annual accounts and consolidated accounts and Regulation (EU) No 537/2014 of the European Parliament and of the Council of 16 April 2014 on specific requirements regarding statutory audit of public-interest entities, as well as Directive 2013/34/ EU of the European Parliament and the Council of 26 June 2013 on annual financial statements consolidated financial statements and related reports of certain types of undertakings, in Ukraine the national accounting legislation was approved (EU, 2006, 2013, 2014). Also, On Amendments to the Law of Ukraine "On Accounting and Financial Reporting in Ukraine" to Improve Certain Provisions (Law No. 2164-VIII, 2017), a new category of public interest entities that provide reporting was defined (Legislation of Ukraine, 1999).

They include securities issuers whose securities are traded on stock exchanges or have been initially publicly offered, banks, insurers, private pension funds, other financial institutions (except other financial institutions and private pension funds belonging to micro and small enterprises) and enter- prises that, according to this Law, belong to large enterprises (Law of Ukraine "On Accounting and Financial Reporting in Ukraine"). The innovations also occurred in regulating the banking audit services market by adopting the Law of Ukraine "On Audit of Financial Statements and Auditing Activities" No. 2258-VIII dated December 21, 2017 (Legislation of Ukraine, 2017). It relates to stricter requirements for auditors who carry out statutory audits of public interest entities, in particular banks.

These requirements include:

- ACU created the sections in the Register of auditors and audit entities ( 3 and 4 ) that contains information about audit entities with the right to conduct a statutory audit of financial statements and a statutory audit of financial statements of public interest enterprises;

- appropriate auditors qualification who inspect public interest entities (audit companies at the main workplace must employ at least five auditors with a total number of full-time qualified employees involved in the completing tasks; at least ten people, at least two of which must approve their qualifications following the Law of Ukraine "On Audit of Financial Statements and Auditing Activities" or have valid certificates (diplomas) of professional organizations confirming a high level of knowledge of IFRS (ACCA, AISRA, ICAEW);

- additional requirements for the selection, appointment and recall of the auditor, his/her independence (not to exceed $15 \%$ of the total net income from the provision of non-audit services and joint audit of such an entity), the prohibition of certain types of non-audit services (complies with European Audit Directives), rotation of the key audit partner every seven years, submission of a comprehensive report on the audit results and quality control inspection by the Audit Public Oversight Body of Ukraine every three years.

In Ukraine, banks with a status of public interest entities are licensed financial institutions, securities issuers and mostly large enterprises (for systemically important banks). Regulators and the public pay attention to the banks' solvency be- 
cause it is vital for financial services consumers in the conditions of bank-centricity of the financial system of Ukraine. An audit is a kind of guarantee of banks' reliability and plays a vital role in building confidence in the banking system.

In addition to the ACU requirements, the NBU established audit companies' regulations to conduct their banks' statutory audit too. They are enshrined in acts such as:

- On the NBU Procedure for Rejection (Disqualification) of an Audit Firm Selected by a Bank for External Audit;

- Rules for Submitting Statistical Reporting to the NBU;

- On approval of the Criteria for audit firms that have the right to assess the bank's financial and economic activities and determine the value of shares to identify the presence/absence of damage caused to the participant (participants) of the bank.

Under the first provision, the NBU can reject an audit company selected by the bank for an external audit. According to the second provision, the bank submits a copy of the contract to the NBU by November 1 of the current year. This contract is concluded with the audit company, which is in the ACU Register. The company must have the right to carry out a statutory audit of public interest enterprises' financial statements.

The criteria applied to audit companies with the right to assess the bank financial and economic activities, determining the value of shares, as well as the presence/absence of damage caused to the participant (participants) of the bank, are as follows:

- an audit company belonging to the section "Audit entities that have the right to conduct a statutory audit of financial statements of the public interest entities" of the Register of auditors and audit entities of the ACU;

- the company is a member of the international audit network according to the "Accountancy Age" and/or "International Accounting Bulletin" for the last three years;
- it operates on the Ukrainian market during the last five years, not less than the last three years of which it conducts a statutory audit of the bank's financial statements (consolidated financial statements);

- it has a partner from the Registers and appraisers of evaluation activity;

- there are no fines for the head of the company, the appraiser's partner by the NBU.

Despite the relatively strict regulation in the banking audit services market, several incidents in the audit practice of the last five years have been reported. It calls into question the auditors' conclusions on bank financial statements' reliability and their solvency. Table 1 summarizes examples of such incidents.

\section{DATA AND METHODS}

Three main data sources were used to describe the banking audit market:

1) Reports of the ACU to the Cabinet of Ministers of Ukraine for 2008-2019 to characterize the potential of the market and banks as public interest entities;

2) The Register of Auditors of Ukraine holding certificates of independent auditors (bank auditors) and the Register of auditing entities that have the right to conduct a mandatory audit of financial statements of public interest entities. These Registers are downloaded from the website of the ACU as of February 22, 2021 in order to differentiate human resources sufficiency for the audit of banks in audit companies of various origins;

3) Annual reporting and reports of independent auditors of 75 Ukrainian banks (public, private and with foreign capital) for 2018 to assess the qualitative criteria for providing audit services.

Structural analysis was used to describe the parameters of the bank audit market (to characterize the sectoral, regional concentration, market segment, 
Table 1. Some incidents related to the banks' audit in Ukraine in 2015-2019

\begin{tabular}{|c|c|c|c|}
\hline & & \multicolumn{2}{|c|}{ Source: Compiled by the authors according to NBU (2019). } \\
\hline Audit company & Bank & Year & Incident solution \\
\hline AF "Donetsk Audit" LLC & $\begin{array}{l}\text { PJSC "All-Ukrainian Development Bank" JSC CB } \\
\text { "Promeconombank" }\end{array}$ & 2015 & \multirow{8}{*}{$\begin{array}{l}\text { Audit companies have been denied to } \\
\text { inspect banks }\end{array}$} \\
\hline AF Bliskor LLC & PJSC "GreenBank" JSC CB "Financial Initiative Bank" & 2015 & \\
\hline $\begin{array}{l}\text { Ukrainian Audit Service } \\
\text { LLC }\end{array}$ & $\begin{array}{c}\text { PJSC "Starokyivskyi Bank", JSC Eurogasbank, JCS "Bank } \\
\text { Golden Gate" }\end{array}$ & 2015 & \\
\hline AF Stavr & JSC CB "Mercury" & 2015 & \\
\hline AF UkrShidAudit & $\begin{array}{l}\text { PJSC CB “Capital”, JSC “Bank Ukoopspilka”, PJSC } \\
\text { "Ukrkommunbank", PJSC CB "Standard”, PJSC "Bank } \\
\text { Cambio", PJSC Terra Bank, PJSC CB "Pivdencombank", } \\
\text { PJSC CB “Ukrainian financial world" }\end{array}$ & 2015 & \\
\hline AF Fincom Audit LLC & $\begin{array}{c}\text { JSC “Delta Bank", PJSC "VAB Bank,", PJSC CB “Daniel”, } \\
\text { PJSC "Primebank" }\end{array}$ & 2015 & \\
\hline AF Consultant LLC & $\begin{array}{l}\text { JSC "Omega Bank", PJSC "Kreditprombank", PJSC "Astra } \\
\text { Bank", PJSC "Radical "Bank, ISC CB "Stolichny Bank" }\end{array}$ & 2015 & \\
\hline AF Oratania LLC & PJSC "Zakhidinkombank" & 2015 & \\
\hline PwC & JSC CB “PrivatBank” & 2017 & $\begin{array}{l}\text { The NBU lost the court, and the right } \\
\text { to inspect banks by the company was } \\
\text { restored }\end{array}$ \\
\hline $\mathrm{BDO}$ & JSC “Fortuna Bank", JSC “Diamantbank", JSC “Apexbank" & 2017 & $\begin{array}{l}\text { BDO lost the court, and the right to inspect } \\
\text { banks by the company was restored after } \\
\text { inclusion in the new register }\end{array}$ \\
\hline AF Aval LLC & - & \multirow{2}{*}{2019} & \multirow{2}{*}{$\begin{array}{l}\text { Companies have been denied to inspect } \\
\text { banks in } 2019\end{array}$} \\
\hline AF "Respect" LLC & - & & \\
\hline
\end{tabular}

study the qualitative audit parameters of banks' reporting by ownership), and dynamic analysis was applied to identify trends in bank audit market potential and volumes of services provided by auditors.

\section{RESULTS}

\subsection{Audit services market for financial companies: dynamics and general trends}

Banks, insurers, and financial companies as public interest entities in the ACU statements are called business entities of the financial sector. The trend of audit services is growing over the past 11 years (in particular, in the field of providing confidence to businesses), as well as the dynamics of this type of service in Ukraine in general.

During 2008-2019, the volume of tasks providing confidence in financial institutions increased 2.5 times. At the same time, the most considerable contribution to its growth in the regional context (Appendix A) was made by Kyiv (Kyiv city), Dnipropetrovsk, Kharkiv, and Lviv regions (in descending order of significance). The leadership of these regions in the Ukrainian audit services market in the financial field is not accidental. These regions are the most economically active. There is the largest number of banks, insurance companies, financial institutions and other public interest entities. In general, they are leaders both in terms of volume and number of services. Zaporizhzhia, Odesa, IvanoFrankivsk and Khmelnytskyi regions are in the top ten regions both in terms of the total volume and number of audit services provided by economic sectors and in the financial field.

The share of this activity in the audit services structure is quite significant and ranges from 15 to $25 \%$ over the last 11 years (Figure 2).

This industry is a leader among other sectors of the economy in terms of audit services. In 2019, only wholesale and retail trade also had a share of $15 \%$ in the volume of provided audit services.

In 2019, audit companies provided financial institutions with 3,472 audit services for the total amount of UAH 273,095.7 thousand.

At the same time, banks are the predominant financial institutions in the structure of the audit 


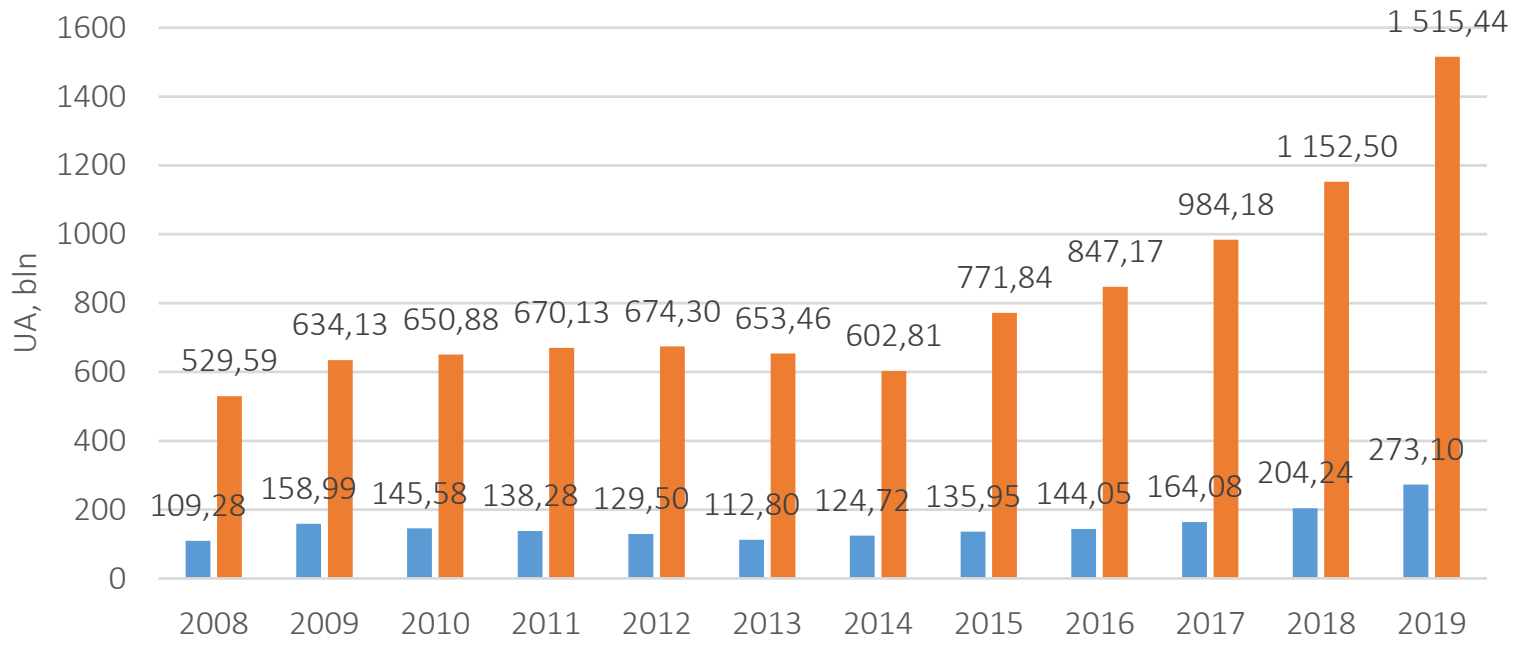

assurance engagement for a bank $\quad$ Assurance engagement, total

Figure 1. The volume of tasks providing confidence in businesses in all sectors of the economy and financial sector of Ukraine, 2008-2019, UAH mln, excluding VAT

services portfolio, as they account for $57 \%$ of the surveyed institutions (Figure 3).

The banks dominate as audit services customers in the market. This is due to the banking-centric origin of the Ukrainian financial sector, prolonged stagnation of the stock market and underdevelopment of institutions that could update the role of audit companies in ensuring transparency of stock market participants.

As of February 1, 2021, there are 73 banks in Ukraine, of which 33 are with foreign capital. They are required to submit annual reports with the au- dit statements to the National Bank of Ukraine by April 30 of each year.

\subsection{Global audit networks and alliances vs. Ukrainian audit companies in the audit market of banking institutions as public interest entities}

The characteristics of financial activities and the banking sector as the audit subject should be supplemented by parameters describing the audit entities that have the right to inspect banks.

Source: Compiled by the authors according to ACU (2008-2019).

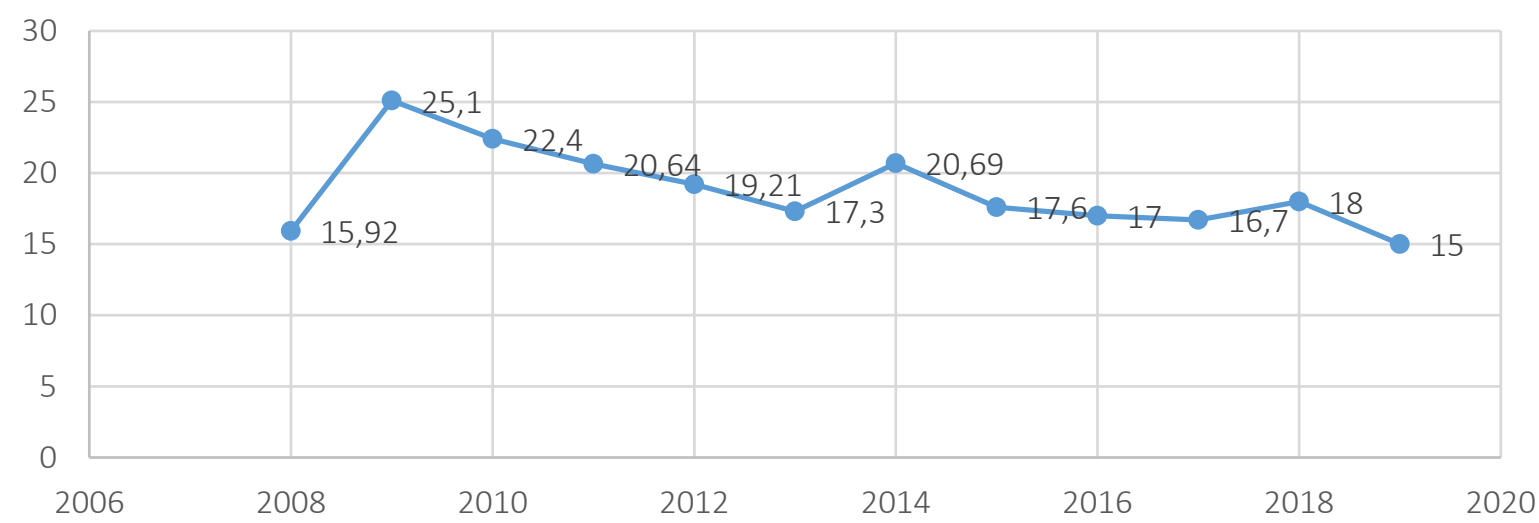

Figure 2. Share of tasks providing confidence in business entities in the financial sector, the total volume of services for $2008-2019, \%$ 


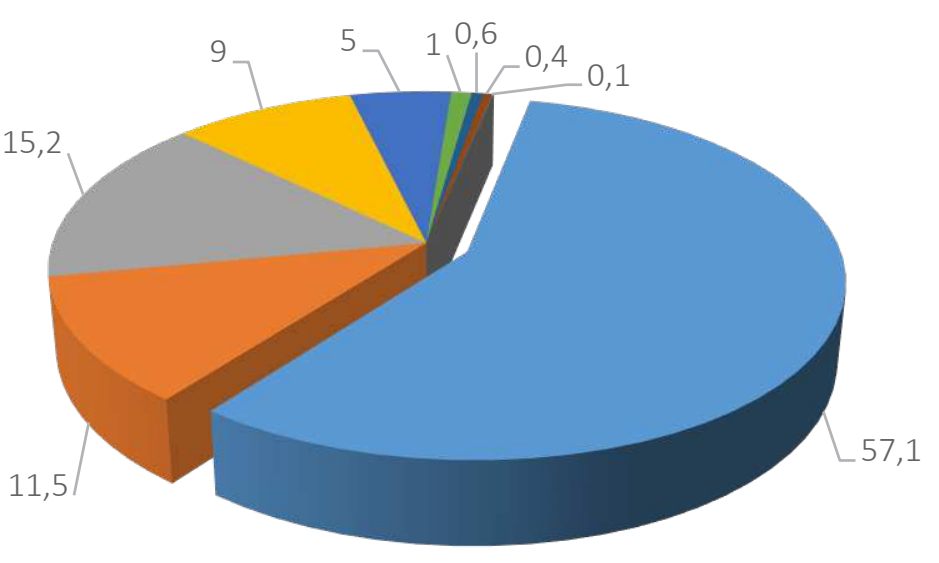

Banks

- Insurance companies

- Other entities in financial sector

- Investment funds

- Asset management companies

Securitites Sellers

non-govermental pension fund

Depositary institutions

Exchanges

Figure 3. Structure of financial institutions that are customers of audit services, the share in the total volume of services provided in $2019, \%$

In particular, the ACU manages a separate section of the register, which contains audit companies with the right to conduct a statutory audit of financial statements of public interest companies. They comply with the Law of Ukraine's specific requirements "On Audit of Financial Statements and Auditing Activities". They have passed inspections of the quality control system of audit services and employ auditors with a bank auditor's valid certificate. Besides, these audit companies meet the Criteria for audit companies that have the right to assess the financial and economic bank activities and determine the value of shares in order to identify the presence/absence of damage to the participant (participants). The National Bank of Ukraine approves them for the annual audit of a particular bank's financial statements under the procedure specified in the Rules for Submitting Statistical Reporting to the NBU based on the results of the annual audit of financial statements.

This section has appeared in the register of audit entities of the ACU after the adoption of the Law of Ukraine "On Audit of Financial Statements and Auditing Activities." So, information on auditors who have the right to conduct a statutory audit of financial statements of public interest companies is available only for the last three years (Table 2).

During 2018-2020, on average 80 audit companies had the right to audit banks as public interest entities. $64 \%$ of them are audit companies from Kyiv city and Kyiv oblast. First of all, such a concentra- tion of audit companies is associated with the level of economic activity in the region and the location of local offices of international networks, alliances and associations (IANAA) of audit companies in the capital of Ukraine. 83\% of IANAA have registered in Kyiv and Kyiv oblast. The top three also include oblasts, which, like Kyiv oblast, have the highest indicators of volume and number of provided audit services.

As of February 17, 2021, there were 218 bank auditors in the Register of Auditors and audit entities of the Audit Chamber of Ukraine, which is only $8.04 \%$ of the total number of auditors in Ukraine (2,711 auditors).

At the same time, out of 218 auditors, 119 were employed in 2020 (in the main workplace or parttime) in audit companies entitled to conduct a statutory audit of financial statements of the public interest companies.

In the banking audit services market, there are 26 public interest companies that are IANAA members, which are in the list of Accountancy Age. In terms of income, a number of auditors and clients are among the top 30 largest networks in the world (Table 3).

Fifteen of these companies were audit entities that had certified bank auditors. The distribution of B4 ("big four") audit companies and international mid-tier accounting companies is presented in the 
Table 2. Dynamics of audit entities entitled to conduct a statutory audit of the financial statements of public interest companies

Source: Compiled by the authors according to the ACU (2021 a, b).

\begin{tabular}{|c|c|c|c|c|c|c|c|}
\hline \multirow[b]{2}{*}{ Region } & \multirow[b]{2}{*}{2018} & \multirow[b]{2}{*}{2019} & \multirow[b]{2}{*}{2020} & \multicolumn{4}{|c|}{ As of February 22, 2021} \\
\hline & & & & $\begin{array}{c}\text { Number } \\
\text { of IANAA, } \\
\text { units } \\
\end{array}$ & $\begin{array}{l}\text { The share of } \\
\text { IANAA, } \%\end{array}$ & $\begin{array}{c}\text { Number of } \\
\text { Ukrainian audit } \\
\text { companies, units }\end{array}$ & $\begin{array}{c}\text { The share of } \\
\text { Ukrainian audit } \\
\text { companies, } \%\end{array}$ \\
\hline Kyiv city and Kyiv Region & 46 & 56 & 52 & 20 & 38.5 & 32 & 61.5 \\
\hline Dnipropetrovsk Oblast & 6 & 6 & 5 & 1 & 20.0 & 4 & 80.0 \\
\hline Kharkiv Oblast & 3 & 6 & 6 & 1 & 16.7 & 5 & 83.3 \\
\hline Zaporizhzhia Oblast & 5 & 5 & 3 & 0 & 0.0 & 3 & 100.0 \\
\hline Odesa Oblast & 4 & 4 & 4 & 0 & 0.0 & 4 & 100.0 \\
\hline Lviv Oblast & 3 & 4 & 4 & 1 & 25.0 & 3 & 75.0 \\
\hline Poltava Oblast & 1 & 2 & 2 & 0 & 0.0 & 2 & 100.0 \\
\hline Zakarpattia Oblast & 1 & 2 & 2 & 1 & 50.0 & 1 & 50.0 \\
\hline Khmelnytskyi Oblast & 1 & 1 & 1 & 0 & 0.0 & 1 & 100.0 \\
\hline Ivano-Frankivsk Oblast & 1 & 1 & 1 & 0 & 0.0 & 1 & 100.0 \\
\hline Vinnytsia Oblast & 1 & 1 & 1 & 0 & 0.0 & 1 & 100.0 \\
\hline Total & 72 & 88 & 81 & 24 & - & 57 & - \\
\hline
\end{tabular}

Table 3. IANAA in the bank audit market as public interest entities

\begin{tabular}{|c|c|c|c|}
\hline $\begin{array}{l}\text { Ukrainian audit company, } \\
\text { IANAA member }\end{array}$ & IANAA & Region & $\begin{array}{c}\text { Bank } \\
\text { auditor's } \\
\text { certificates }\end{array}$ \\
\hline PKF Ukraine LLC & PKF International Limited & Kyiv & 10 \\
\hline RSM Ukraine Service LLC & RSM International & Kyiv & 9 \\
\hline Deloitte Ukraine LLC & Deloitte Touche Tohmatsu Limited & Kyiv & 8 \\
\hline PJSK KPMG & KPMG International Limited & Kyiv & 7 \\
\hline Ernst \& Young LLC & Ernst \& Young Global Limited & Kyiv & 7 \\
\hline PWC LLC & PricewaterhouseCoopers Global Network & Kyiv & 5 \\
\hline BDO LLC & BDO & Dnepropetrovsk & 5 \\
\hline Baker Tilly LLC & BAKER TILLY INTERNATIONAL & Kyiv & 4 \\
\hline Active-Audit LLC & AGN INTERNATIONAL & Kyiv & 4 \\
\hline Kreston LLC & Kreston International & Kyiv & 4 \\
\hline Crowe Erfolg Ukraine LLC & \multirow{3}{*}{ Crowe Global } & Kyiv & 2 \\
\hline AC Crowe Ukraine LLC & & Kyiv & 2 \\
\hline Inter-Audit Crowe LLC & & Kyiv & 2 \\
\hline HLB Ukraine LLC & HLB International & Kyiv & 1 \\
\hline LLC AF Kyiv Audit Group & $\begin{array}{l}\text { Praxity (International Alliance of Independent Accounting } \\
\text { and Auditing Companys), Associate Member }\end{array}$ & Kyiv & 1 \\
\hline AF P.S.P. AUDIT LLC & $\begin{array}{l}\text { International network of audit, tax, accounting and } \\
\text { consulting companies MGI Worldwide }\end{array}$ & Kyiv & 1 \\
\hline JPA Ukraine LLC & JPA International & Kyiv & 0 \\
\hline LLC MTD AUDIT & Audit network ICAAP & Kyiv & 0 \\
\hline AF Moore Stephens LLC & Moore Global & Kyiv & 0 \\
\hline LLC "Aksonova \& Associates" & "GG Geneva Group International AG Zurich» (Switzerland) & Kyiv & 0 \\
\hline LLC AC "DiViSe Group" & INPACT & Kyiv & 0 \\
\hline Grant Thorton Legis LLC & Grant Thornton International & Kyiv & 0 \\
\hline Russel Bedford RCG LLC & Russell Bedford International & Kyiv & 0 \\
\hline Mazars Ukraine LLC & Mazar Group & Kyiv & 0 \\
\hline Varianta LLC & JPA International & Zakarpatska & 0 \\
\hline Nexia DK Audit and Consulting LLC & Nexia International & Lviv & 0 \\
\hline Rödl \& Partner LLC & Rodl \& Partner & Kharkiv & 0 \\
\hline
\end{tabular}


proportion of $40 \%$ to $60 \% .40 \%$ of all IANAA auditors with bank certificate work for B4 companies.

However, some mid-tier audit companies (PKF Ukraine LLC, RSM Ukraine Service LLC) have ten auditors with bank auditor certificates. That is higher than in some B4 companies. The rest of the mid-tier audit companies has four or fewer bank auditors.

There are 45 auditors in 11 Ukrainian non-IANAA companies (Table 4) that have the opportunity to conduct an audit of banks.

Table 4. Ukrainian companies in the bank audit market as public interest entities

Source: Compiled by the authors using data from the ACU (2021a, b).

\begin{tabular}{|c|c|c|}
\hline $\begin{array}{l}\text { Ukrainian audit } \\
\text { companies }\end{array}$ & Region & $\begin{array}{c}\text { Number } \\
\text { of bank } \\
\text { auditors }\end{array}$ \\
\hline Ukrainian audit service LLC & Kharkiv & 7 \\
\hline De Visu PJSK & Kyiv & 6 \\
\hline Kiev Audit LLC & Kyiv & 6 \\
\hline $\begin{array}{l}\text { LLC "International Financial } \\
\text { Audit" }\end{array}$ & Kyiv & 5 \\
\hline $\begin{array}{l}\text { Audit Company Ukraudit XXI- } \\
\text { Zahid LTD }\end{array}$ & Lviv & 4 \\
\hline$A F$ "Respect"' LLC & Odesa & 4 \\
\hline ACF Grantie & Odesa & 4 \\
\hline LLC AF Capital Plus & Kyiv & 4 \\
\hline LLC AF Cooperwood & Dnepropetrovsk & 2 \\
\hline LLC Audit-Service INC & Ivano-Frankivsk & 2 \\
\hline AF Teo-Audit LLC & Kyiv & 1 \\
\hline
\end{tabular}

Simultaneously, the number of bank auditors employed in IANAA is $60.2 \%$ higher than in Ukrainian firms without network status.

\subsection{Assuring the Ukrainian banks' statements: quality criteria}

A comprehensive study of banks' statements was conducted to form a characteristic of the audit companies and how they performed tasks providing confidence in the Ukrainian banks' statements as public interest entities. The study is based on the results of 2018 that were published during 2019-2020 on banks' websites and collected as of January 1, 2020.

The study of banks' annual reporting was conducted according to the following criteria:

- availability of a report of independent auditors; company status (Big 4, a mid-tier company, a Ukrainian company entitled to audit banks as public interest entities);

- auditor's conclusion (positive, modified (with notification), refusal to provide a conclusion).

The study results of the bank statement on each of the criteria are given in Table 5 .

Contrary to commonly accepted belief, the bank cannot file an audit report on annual reports to the NBU due to regulatory sanctions (according to the first criterion) as part of the annual information of banks (JSC "Bank Alliance", PJSC "Commercial Bank" Globus", JSC "Bank Avangard”). Auditors did not confirm management reports.

When characterizing the bank audit market according to the second criterion (the audit company's status), it should be noted that there is a common trend among the studied 75 banks. B4 auditors and the mid-tier companies audit the largest banks (state and with foreign capital). The share of these companies in the bank audit market is $85 \%$ (34\% of B4). 15\% (11 banks out of 75 ) are audited by Ukrainian audit firms that are not part of IANAA.

A detailed analysis of the banks' audit portfolios in these segments (Figure 4) shows that among B4 companies, the year under study is very significant as $\mathrm{PwC}$ was omitted. At that time, one of the main audit players was removed by the NBU after the incident with JSC CB "PrivatBank".

At the same time, 11 banks, mainly those with foreign capital, were included in the KPMG portfolio, eight (state and foreign equally) - in the EU portfolio, and seven - mainly with foreign capital in the DT portfolio.

The mid-tier audit companies' leaders are representatives of the international networks PKF and AGN, which inspect 12 and 11 Ukrainian banks, respectively (Figure 5). The share of only these two companies is $31 \%$ of the total number of analyzed banks.

The Ukrainian audit firms' audit portfolio is quite simple, namely $15 \%$ of the study sample (Figure 6). Determination of the leader in this segment is un- 
Table 5. Characteristics of audit statements of Ukrainian banks as public interest entities

Source: Compiled by the authors according to the aggregated bank reporting data.

\begin{tabular}{|c|c|c|c|c|c|c|c|c|c|c|c|c|c|}
\hline \multirow{3}{*}{ Property } & \multirow{3}{*}{ Banks } & \multirow{2}{*}{\multicolumn{2}{|c|}{$\begin{array}{c}\text { Availability of } \\
\text { a report }\end{array}$}} & \multicolumn{6}{|c|}{ Company status } & \multicolumn{4}{|c|}{ Conclusion } \\
\hline & & & & \multicolumn{2}{|l|}{ B4 } & \multicolumn{2}{|c|}{$\begin{array}{l}\text { The mid-tier } \\
\text { companies, } \\
\text { IANAA }\end{array}$} & \multicolumn{2}{|c|}{ Ukrainian } & \multicolumn{2}{|c|}{ Positive } & \multicolumn{2}{|c|}{$\begin{array}{c}\text { With } \\
\text { notification }\end{array}$} \\
\hline & & Number & $\%$ & Number & $\%$ & Number & $\%$ & Number & $\%$ & Number & $\%$ & Number & $\%$ \\
\hline $\begin{array}{l}\text { Public- } \\
\text { owned }\end{array}$ & 5 & 5 & 100 & 5 & 100 & 0 & - & 0 & - & 4 & 80 & 1 & 20 \\
\hline $\begin{array}{l}\text { With foreign } \\
\text { capital }\end{array}$ & 20 & 20 & 100 & 12 & 60 & 8 & 40 & 0 & - & 18 & 90 & 2 & 10 \\
\hline $\begin{array}{l}\text { Privat- } \\
\text { owned }\end{array}$ & 50 & 47 & 94 & 9 & 18 & 30 & 60 & 11 & 22 & 42 & 84 & 8 & 16 \\
\hline Total & 75 & 72 & - & 26 & - & 38 & - & 11 & - & 64 & - & 11 & - \\
\hline
\end{tabular}

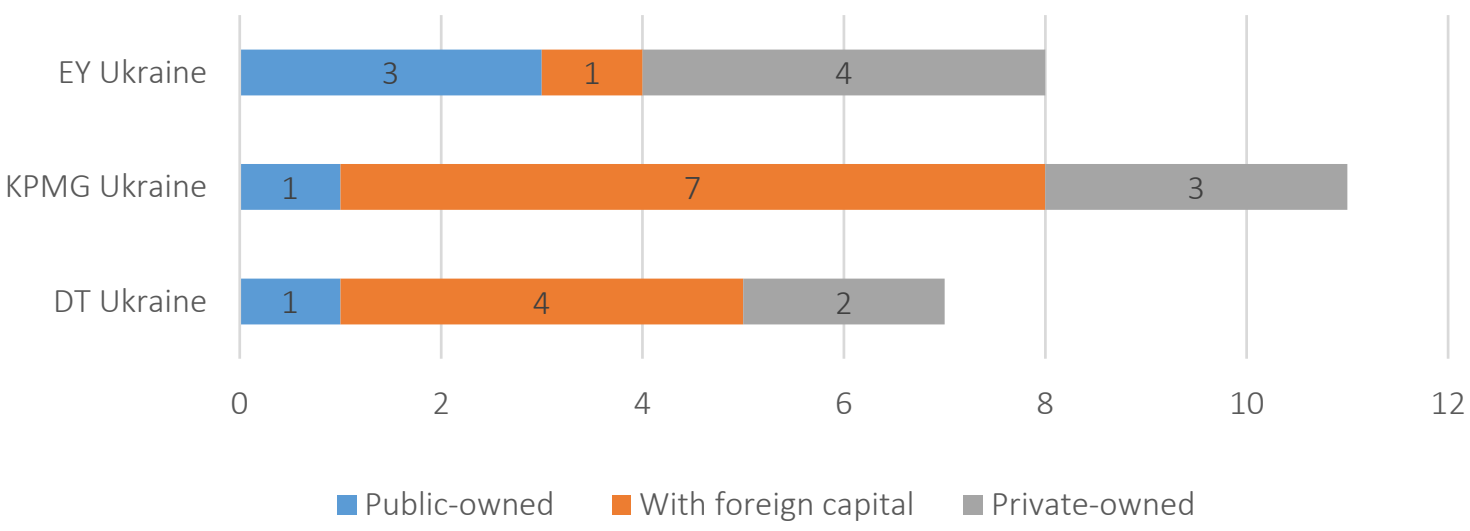

Figure 4. Audit portfolio of Ukrainian banks of B4 companies

Source: Compiled by the authors according to the aggregated bank reporting data.

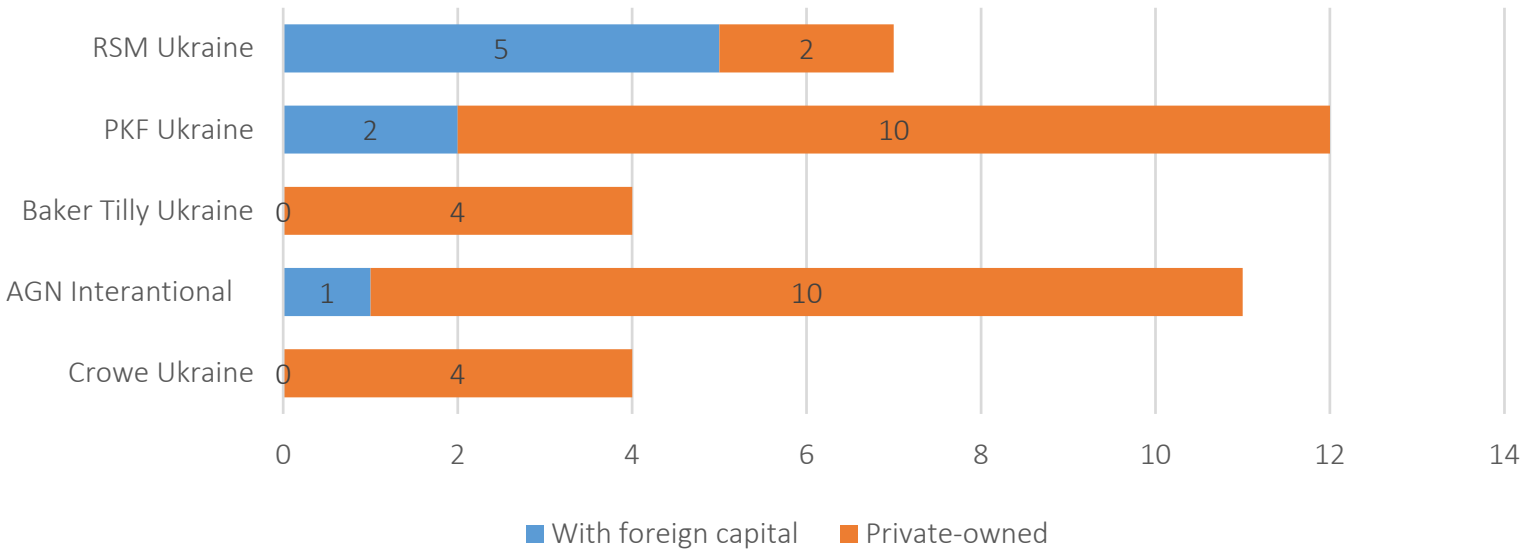

Figure 5. Audit portfolio of Ukrainian banks of the mid-tier audit companies

motivated, given the relatively equal distribution The auditors' conclusions in the reports show mostly of banks by companies (2-3 banks).

All banks included in the portfolio are banks with positive opinion about the reliability and disclosure in the banks' financial statements. $85 \%$ of the auprivate capital and do not hold leading positions dit reports had a positive opinion, $15 \%$ positive, but in banking activities. with one notification. The conclusions for JSC CB "PrivatBank" (state), Forward Bank, BTA Bank (with 


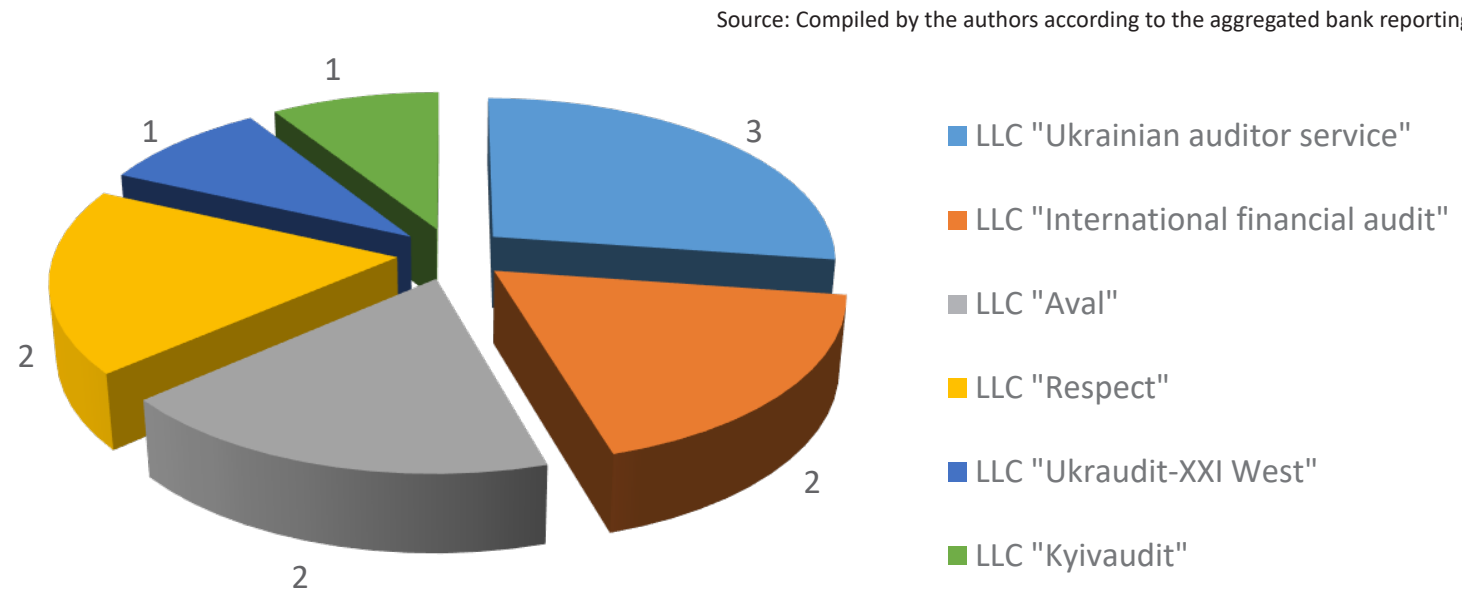

Figure 6. Audit portfolio of Ukrainian banks of Ukrainian audit companies

foreign capital) and eight banks with private capital (A-Bank, Arcada, Bank investments and savings, SC CB Zemelny Capital, JSC "Commercial Investment Bank", JSC Sky Bank, Ukrbudinvestbank, and JSC European Industrial Bank) were with notifications. At the same time, Bank Arcada was declared insolvent on August 25, 2020.
In general, the conclusions of auditors at first glance indicate a high level of trust and transparency in banks' reporting. However, given the experience of existing incidents in the market, a more detailed analysis with a broader time frame is required.

\section{CONCLUSION}

The study of this market was conducted in three aspects: from the financial sector and banks (market potential), auditors (ability to provide audit services), and in terms of market segmentation and company status (potential and capacity). Audit services provided to banks as public interest entities were also characterized by regional, sectoral structure and dynamic characteristics.

Based on the analysis of the ACU reports for 2008-2019, the leading positions of financial institutions and banks as potential objects of audit were identified, as well as regional market concentration in economically active regions. Systematization of data from the register of auditors of Ukraine by ACU indicates the concentration of human resources for auditing banks in MMAA and B4 companies. Qualitative criteria for the annual reports of 75 Ukrainian banks show that the largest banks (stateowned and foreign-owned) are audited by B4 auditors and second-tier companies. However, the prevalence of positive audit opinions on the reporting of banks cannot be regarded as a guarantee of their solvency for consumers of financial services and requires further study.

These results show the presence of market segmentation by the following groups of audit firms that have the right to inspect banks: Segment B4; Segment of mid-tier companies with the number of bank auditors exceeding some B4, Segment of the mid-tier companies with 4 or less banks auditors, and Segment of Ukrainian audit firms.

The conclusions can be useful both for the regulators of the audit services market - the ACU in terms of forming a competitive market structure, and the NBU to ensure transparency and reliability of banks as public interest entities.

Prospects for further research are to study the segmentation of the banking audit services market as public interest entities based on annual reports for 2019 and 2020. In particular, it will be useful to study 
the redistribution of bank clients in the portfolios of audit firms, including B4, after PwC's return to this market, compliance with the NBU requirements regarding the deviation of audit firms from auditing banks.

\section{AUTHOR CONTRIBUTIONS}

Conceptualization: Victor Sukhonos, Serhiy Makarenko, Viktoriia Levkulych.

Data curation: Yulia Serpeninova, Galina M. Kolisnyk.

Formal analysis: Yulia Serpeninova, Galina M. Kolisnyk.

Funding acquisition: Serhiy Makarenko.

Investigation: Serhiy Makarenko.

Methodology: Serhiy Makarenko, Viktoriia Levkulych, Galina M. Kolisnyk.

Project administration: Victor Sukhonos, Yulia Serpeninova.

Resources: Serhiy Makarenko.

Software: Serhiy Makarenko, Viktoriia Levkulych.

Supervision: Victor Sukhonos, Galina M. Kolisnyk.

Validation: Yulia Serpeninova, Galina M. Kolisnyk.

Visualization: Viktoriia Levkulych.

Writing - original draft: Victor Sukhonos, Serhiy Makarenko.

Writing - reviewing \& editing: Victor Sukhonos, Yulia Serpeninova, Viktoriia Levkulych.

\section{ACKNOWLEDGMENT}

Comments from the Editor and anonymous referees have been gratefully acknowledged. Serhiy Makarenko gratefully acknowledges financial support from the Ministry of Education and Science of Ukraine (0121U100473)

\section{REFERENCES}

1. Audit Chamber of Ukraine (ACU). (2008-2019). Audit Chamber of Ukraine information regarding the audit in Ukraine. Retrieved from https://www.apu.net.ua/zvit-do$\mathrm{kmu}$

2. Audit Chamber of Ukraine (ACU). (2021a). Register of the Audit Chamber of Ukraine. Auditors in Ukraine. Retrieved from https:// www.apu.com.ua/audytory/

3. Audit Chamber of Ukraine (ACU). (2021b). Auditing entities that have the right to conduct a statutory audit of the financial statements of public interest entities. Retrieved from https://www.apu.com.ua/ subjekty-audytorskoi-dijalnostijaki-majut-pravo-provodyty-obovjazkovyj-audyt-finansovoi-zvitnosti pidpryjemstv-shho-stanovljatsuspilnyj-interes/

4. Bratten, B., Causholli, M., \& Omer, T. C. (2019). Audit Firm Tenure, Bank Complexity, and Financial
Reporting Quality. Contemporary Accounting Research, 36(1), 295325. https://doi.org/10.1111/19113846.12427

5. European Union (EU). (2006). Directive 2006/43/EC of the European Parliament and of the Council of 17 May 2006 on statutory audits of annual accounts and consolidated accounts, amending Council Directives 78/660/EEC and 83/349/EEC and repealing Council Directive 84/253/ EEC. Retrieved from https://eurlex.europa.eu/legal-content/EN/ $\mathrm{TXT} /$ ?uri $=$ celex\%3A32006L0043

6. European Union (EU). (2013). Directive 2013/34/EU of the European Parliament and the Council of 26 June 2013 on annual financial statements consolidated financial statements and related reports of certain types of undertakings, amending Directive 2006/43/EC and repealing Council
Directives 78/660/EEC and 83/349/ EEC Text with EEA relevance of the European the European Parliament and the Council. Retrieved from http://eur-lex. europa.eu/legal-content/EN/ TXT/?uri=celex:32013L0034

7. European Union (EU). (2014). Regulation (EU) No 537/2014 of the European Parliament and of the Council of 16 April 2014 on specific requirements regarding statutory audit of publicinterest entities and repealing Commission Decision 2005/909/ EC (Text with EEA relevance). Retrieved from https://eur-lex. europa.eu/legal-content/EN/ TXT/?uri=CELEX:32014R0537

8. Huizinga, H., \& Laeven, L. (2012). Bank valuation and accounting discretion during a financial crisis. Journal of Financial Economics, 106(3). https://doi.org/10.1016/j. jfineco.2012.06.008 
9. Jin, J. Y., Kanagaretnam, K., \& Lobo, G. J. (2011). Ability of accounting and audit quality variables to predict bank failure during the financial crisis. Journal of Banking and Finance, 35(11), 2811-2819. https://doi.org/10.1016/j.jbankfin.2011.03.005

10. Legislation of Ukraine. (1999). Law of Ukraine "On Accounting and Financial Reporting in Ukraine" dated July 16, 1999 No. 996-XIV (Edition from November 14, 2020). (In Ukrainian). Retrieved from https://zakon.rada. gov.ua/laws/show/996-14\#Text

11. Legislation of Ukraine. (2017). Law of Ukraine "On Audit of Financial Statements and Auditing Activities" dated December 21, 2017 No. 2258-VIII (Edition from July 1, 2020). (In Ukrainian). Retrieved from https://zakon.rada. gov.ua/laws/show/2258-19\#Text

12. Legislation of Ukraine. (2018a). Resolution of the Board of the National Bank of Ukraine "On the NBU Procedure for Rejection (Disqualification) of an Audit Firm Selected by a Bank for External Audit" No. 89 dated August 2, 2018. (In Ukrainian). Retrieved from https://zakon.rada.gov.ua/laws/ show/v0089500-18\#Text

13. Legislation of Ukraine. (2018b). Resolution of the Board of the National Bank of Ukraine "The Rules for Submitting Statistical Reporting to the NBU"No. 90 dated August 2, 2018. (In Ukrainian). Retrieved from https://zakon.rada.gov.ua/laws/ show/v0090500-18\#Text

14. Legislation of Ukraine. (2020). Resolution of the Board of the National Bank of Ukraine "On approval of the Criteria for audit firms that have the right to assess the bank's financial and economic activities and determine the value of shares to identify the presencel absence of damage caused to the participant (participants) of the bank" No. 80 dated June 22, 2020. (In Ukrainian). Retrieved from https://zakon.rada.gov.ua/laws/ show/v0080500-20\#Text

15. Makarenko, I., Sukhonos, V., Zhuravlyova, I., Legenchuk, S., \&
Szołno, O (2020). Sustainability reporting assessment for quality and compliance: the case of Ukrainian banks' management reports. Banks and Bank Systems, 15(2), 117-129. doi:10.21511/bbs.15(2).2020.11

16. NBU. (2019) The National Bank rejected two audit companies from conducting an external audit of banks. (In Ukrainian). Retrieved from https://bank.gov.ua/ua/news/ all/natsionalniy-bank-vidhilivdvi-auditorski-kompaniyi-vidprovedennya-zovnishnogo-audituv-bankah

17. Norton, S. D. (2012). Bank Failures and Accounting During the Financial Crisis of 20082009. In Creative Accounting, Fraud and International Accounting Scandals. https://doi. org/10.1002/9781119208907.ch20

18. Redko, O. (2020). The Yanus-Like Quality of the Ukrainian Audit. Scientific Bulletin of the National Academy of Statistics, Accounting and Audit, 3, 70-76. https://doi. org/10.31767/nasoa.3-2020.07

19. Rewczuk, K., \& Modzelewski, P. (2019). Determinants of audit fees: Evidence from Poland. Central European Economic Journal, 6(53), 323-336. https://doi.org/10.2478/ ceej-2019-0020

20. Shendryhorenko, M., \& Shevchenko, L. (2018). Urgent issues of organization of audit activity in Ukraine and directions for their solutions. Baltic Journal of Economic Studies, 4(1), 345-349. https://doi.org/10.30525/22560742/2018-4-1-345-349

21. The Financial Times (FT). (2017). Ukraine pulls PwC bank audit license over USD 5.5 bn hole at top lender. Retrieved from https:// www.ft.com/content/9a46c8186d7e-11e7-b9c7-15af748b60d0

22. The Guardian. (2010) Auditors' role in Lehman's collapse unites opposition in calls for reform. Retrieved from https://www. theguardian.com/business/2010/ mar/15/auditors-role-lehmancollapse-critics

23. Wiggins, R. Z., Bennett, R. L., \& Metrick, A. (2019). The Lehman Brothers Bankruptcy D: The
Role of Ernst \& Young. Journal of Financial Crises, 1(1), 100-123. Retrieved from https://elischolar. library.yale.edu/cgi/viewcontent. cgi article $=1003 \&$ context $=$ journal-of-financial-crises

24. Zhuravka, F., Kravchenko, O., Ovcharova, N., Oleksich, Zh., \& Miroshnychenko, O. (2020). Impact of integrated reporting on enterprise valuebased management: evidence from Ukraine. Problems and Perspectives in Management, 18(2), 154-165. https://doi.org/10.21511/ ppm.18(2).2020.14 


\section{APPENDIX A}

Table A1. Number of assurance tasks performed by audit firms on behalf of financial entities

Source: Compiled by the authors according to ACU.

\begin{tabular}{|c|c|c|c|c|c|c|c|c|c|c|c|c|}
\hline Oblast & 2008 & 2009 & 2010 & 2011 & 2012 & 2013 & 2014 & 2015 & 2016 & 2017 & 2018 & 2019 \\
\hline $\begin{array}{l}\text { The Autonomous } \\
\text { Republic of Crimea }\end{array}$ & 255.7 & 540.00 & 335.4 & 408.5 & 224.9 & 325.7 & 120.5 & 0 & 0 & 0 & 0 & $\mathrm{n} / \mathrm{a}$ \\
\hline Vinnytsia & 43.6 & 58.00 & 41.7 & 67.8 & 97.1 & 102.7 & 129 & 104.5 & 104.5 & 155.8 & 145.5 & $\mathrm{n} / \mathrm{a}$ \\
\hline Volyn & 179.7 & 124.5 & 94.9 & 209 & 128.5 & 70.5 & 53 & 55 & 858 & 155 & 62 & $\mathrm{n} / \mathrm{a}$ \\
\hline Dnipropetrovsk & $3,099.10$ & $5,309.50$ & $5,699.30$ & $5,584.50$ & $9,132.9$ & $6,504.10$ & $4,790.00$ & $6,840.9$ & $8,444.00$ & $5,104.80$ & $5,203.80$ & $n / a$ \\
\hline Donetsk & 490.9 & $1,067.00$ & 996.9 & $1,276.20$ & $1,497.9$ & $1,920.80$ & 614.7 & 205.2 & 103 & 55 & 30 & $n / a$ \\
\hline Zhytomyr & 19.7 & 7.40 & 13.2 & 33 & 50.2 & 45.7 & 0 & 0 & 0 & 0 & 0 & $n / a$ \\
\hline Zakarpattia & 41.9 & 58.70 & 52.6 & 49.4 & 83.7 & 96 & 30.1 & 0 & 0 & 0 & 0 & $n / a$ \\
\hline Zaporizhzhia & 818.2 & $1,018.30$ & 659.5 & 623.9 & 749.8 & 968.1 & 743.6 & 863.6 & $1,037.70$ & $1,683.00$ & $2,276.70$ & $n / a$ \\
\hline Ivano-Frankivsk & 134.2 & 177.2 & 418.4 & 257.4 & 345.5 & 136.8 & 127.3 & 278 & 3323.90 & 804.7 & 871 & $n / a$ \\
\hline Kyiv city. Kyiv oblast & $99,924.50$ & $146,078.30$ & $133,365.80$ & $125,492.20$ & $112,519.9$ & $97,164.00$ & $112,644.80$ & $123,085.7$ & $125,379.70$ & $147,608.30$ & $185,183.1$ & $n / a$ \\
\hline Kirovohrad & 19 & 18.20 & 27.9 & 66.9 & 36.4 & 92 & 129 & 105.2 & 38.6 & 86.5 & 106.1 & $n / a$ \\
\hline Luhansk & 86.7 & 96.7 & 75.1 & 104.5 & 126.8 & 149.2 & 121 & 0 & 0 & 0 & & $n / a$ \\
\hline Lviv & $1,053.80$ & 973.20 & 411 & 643.7 & 547.8 & 794.9 & 683.1 & 590.7 & $1,015.10$ & $1,354.80$ & $2,319.50$ & $n / a$ \\
\hline Mykolaiv & 46 & 58.3 & 40.2 & 26.2 & 33.3 & 27.5 & 0 & 5 & 0 & 0 & 0 & $n / a$ \\
\hline Odesa & 476.1 & 902.30 & 609.1 & 580.9 & 538.2 & 643 & 728.3 & 481.6 & 643 & 1567.20 & 608.8 & $n / a$ \\
\hline Poltava & 143.1 & 104.5 & 84 & 75.9 & 68.7 & 116.5 & 222 & 167 & 315 & 383 & 471 & $\mathrm{n} / \mathrm{a}$ \\
\hline Rivne & 10.4 & 10.40 & 8.8 & 14.7 & 153.2 & 5 & 0 & 0 & 0 & 0 & 0 & $n / a$ \\
\hline Sumy & 33.5 & 27.60 & 39.8 & 434.2 & 43.8 & 51.3 & 0 & 0 & 0 & 0 & 0 & $n / a$ \\
\hline Ternopil & 208.6 & 252.10 & 218.1 & 70.1 & 535.5 & 479 & 927 & $1,041.6$ & 878 & $1,268.30$ & $1,581.20$ & $n / a$ \\
\hline Kharkiv & $1,794.00$ & $1,712.00$ & $2,046.70$ & $1,725.60$ & $2,204.2$ & $2,609.50$ & $2,271.30$ & $1,742.2$ & $1,188.00$ & $3,024.00$ & $4,203.60$ & $n / a$ \\
\hline Kherson & 42.7 & 46.4 & 97.7 & 103.9 & 48.3 & 50 & 93.6 & 37.2 & 173.5 & 213.5 & 255 & $\mathrm{n} / \mathrm{a}$ \\
\hline Khmelnytskyi & 43 & 98.7 & 59.2 & 90 & 161.4 & 120.3 & 161.7 & 129 & 166.9 & 403.3 & 267.1 & $\mathrm{n} / \mathrm{a}$ \\
\hline Cherkasy & 156 & 9.50 & 84.9 & 46.4 & 66.5 & 55.8 & 134.3 & 221.3 & 375.6 & 209 & 652.5 & $\mathrm{n} / \mathrm{a}$ \\
\hline Chernivtsi & 47 & 66.40 & 25.5 & 27.4 & 6.7 & 25.1 & 0 & 0 & 0 & 0 & 0 & $\mathrm{n} / \mathrm{a}$ \\
\hline Chernihiv & 110.6 & 124.40 & 76.2 & 105 & 81.8 & 64 & 0 & 0 & 0 & 0 & 0 & $n / a$ \\
\hline $\begin{array}{l}\text { Total tasks providing } \\
\text { assurance to the } \\
\text { entities in the financial } \\
\text { sector }\end{array}$ & 109,278 & $158,989.6$ & $145,581.9$ & $138,282.7$ & $129,498.8$ & $112,804.9$ & $124,724.3$ & 135,954 & 144,045 & 164,076 & $204,236.9$ & $273,095.7$ \\
\hline $\begin{array}{l}\text { Total tasks providing } \\
\text { assurance }\end{array}$ & $529,586.90$ & $634,131.3$ & $650,879.50$ & $670,125.4$ & $674,296.2$ & 653,460 & $602,812.1$ & $771,840.1$ & 847,171 & 984,180 & $1,152,503.9$ & $1,515,440.7$ \\
\hline
\end{tabular}

